\title{
Society Perception Toward Harmonization of Social Relationship Ethnic in Malaysia
}

\author{
*Igus Nurjanah ${ }^{1}$ and Anis Satila Binti Mat Arifin ${ }^{2}$ \\ 1) Graduate Student of Geography Education, Universitas Negeri Padang, Indonesia \\ e-mail: igus.nurjanah86@gmail.com \\ 2) Student of Geography, Malaya University, Malaysia \\ e-mail: anyssnisha@gmail.com
}

*Corresponding Author, Received: September 14, 2018, Revised: October 21, 2018, Accepted: December 05, 2018

This is an open acces article distributed under the Creative Commons 4.0 Attribution License, wich permits unrestricted use, Distribution and reproduction in any medium provided the original work is properly cited @2017 by author and Universitas Negeri Padang

\begin{abstract}
This research to describe society perceptions of the harmonization of ethnic social relations in Malaysia. Malaysia is a multi-ethnic, multi-cultural and multi-lingual society. This type of research is qualitative descriptive, using several informants to conduct interviews. Data sources used are primary sources, namely information that is sourced directly from the research location by means of interviews. Whereas secondary sources are data obtained from documentation or literature study to complete primary data, with sampling technique, accidental sampling. The results of the research show that social relations between ethnic groups in Malaysia have been well established by maintaining togetherness and mutual respect between individuals and community groups. However, both the community and the government still have to strive to keep working together in maintaining the harmony of social relations that have been well established, so that the creation of a sense of security and comfort despite being in an environment with ethnic diversity.
\end{abstract}

Keywords: Perception, Harmonization, Ethnicity, Malaysia

\section{Introduction}

Malaysia is a country that has ethnic and cultural diversity, as Malaysian people who live in differences, whether ethnicity and culture must have the nature of awareness that is able to maintain the relationship between individuals with individuals or groups with groups that live side by side in a community environment itself, so that community relations are well established and respect each other in carrying out their activities which can provide negative responses from certain groups or individuals. Humans are social beings who need relationships with others. Humans want to get attention among others and groups, to get that is needed a relationship and use various means, tools and media and others. Communication effectiveness theory is put forward about the importance of social contacts for humans and society, in making various contacts or relationships in different ways and styles (Mulyana, 2005; Hermon et al., 2018). The nature of social life consists of the number of actions and reactions that are fairly numerous, both between individuals and between groups. The parties involved adjust to one of the collective behavioral patterns. Unity that comes from self-adjustment, we call groups or communities (Veeger, 1985).

Ethnicity or ethnicity is a human association because of the similarity of race, religion, national origin or combination of these categories which are tied to the system of cultural values, whereas according to Indonesian encyclopedias ethnic means social groups in social or cultural systems that have a certain meaning or position because of descent, custom, religion, language, and so on. Members of an ethnic group have similarities in terms of history (descent), language (whether used or not), value systems, and customs and traditions (Gazza, 2012). Furthermore, it needs to be realized that in a social interaction, in reality 
various ethnic groups are not in the same position. There are tribes that occupy a position as a superordinate group, on the contrary there are also ethnic groups that are serada in subordinate groups. There are times when the superordinate group is also the dominant group that has a higher and certain privileges (Poerwanto, 2000).

A "status" separation that develops into a different "caste" structure from a mere "ethnic" separation, caste structure transforms horizontal coexistence and does not intersect with various ethnically separated groups into a supra vertical and subordinated social system (Weber, 2006). It has been described on the face of humans that they are living beings that are more perfect when compared to other living things. As a result of the elements of life that exist in humans, humans develop and experience changes in segifisiologis and changes in psychological terms (Walgito, 1980). Social change cannot be separated from cultural change. This is because culture is the result of the existence of society, so that there is no culture if there is no community that supports it and no community has no culture (Setiadi et al., 2006). Social change is experienced by every community which basically cannot be separated by changes in the culture of the community concerned. Social change can encompass all aspects of the life of the interaction of the more rational fellow citizens, changes in economic attitudes and orientations become increasingly commercial, daily work procedures are increasingly characterized by the division of labor in increasingly sharp specialization of activities, changes in institutional and community leadership that are increasingly democratic, changes in procedures and tools of activities that are more efficient and others. Changes that occur in society today are normal symptoms. In a fast tempo, the influence can spread to other parts through modern communication (Masri, 2011). Social changes that occur in the community are very broad, diverse, and unlimited regarding changes in social values, social norms, organizational behavior patterns, the composition of correctional institutions, social layers, power and authority, social interaction and so on (Ismawati, 2012; Hermon, 2010; Hermon, 2012).

The life of people who have various groups or ethnic groups cannot be denied by the existence of class characteristics such as smaller ethnic groups or groups if they have lived for a long time always have: In-group feeling, namely the feeling that always defends the truth of the group, hates and suspects everything that comes from the outside. These feelings that bring prejudice or prejudice that is not easily lost to other groups (Hassan, 1993; Hermon, 2016; Hermon, 2017). The socio-cultural existence of a nation that lives in the midst of society is a unity which has intertwined parts between one another and is bound by internal ties which are a reflection of the moral sense and historical value of a nation. These bonds in turn accumulate and give a distinctive character to human culture, while reflecting a special character for the way of life and individual and community behavior. The translation of the culture developed was able to define the individual privileges dynamically in humanity. The creation of balance and shock, consensus and disputes, harmony and disputes, cooperation and conflict, peace and war, prosperity and crisis and so on, are part of a complex social system

Malaysia is a multi-ethnic, multi-cultural and multi-lingual society. The population in February 2007 was 26.6 million consisting of 62\% Bumiputera (including Malays), 24\% Chinese, 8\% Indians, with few minorities and indigenous tribes. Malaysians, Chinese, Indians and many other ethnic groups have lived together in Malaysia for generations. All these cultures have influenced each other, which creates true Malaysian culture. The largest ethnic groups in Malaysia are Malays, Chinese and Indians. In Sabah and Sarawak, there are various indigenous ethnic groups with their own unique culture and heritage. However, there is one crisis in their society that cannot be denied. The Malaysian government still practices sharp ethnic distinctions. The Malay people are racist and discriminatory towards other ethnic groups, namely China and India. It turned out that this attitude had been maintained by the bumiputera, the nickname of Malaysia for the Malay race, for a long time. Long before Malaysia became independent, inter-ethnic friction often occurred. The reason is that the Chinese nation controls all sectors of the economy. Ethnic Malays often lose competitiveness with the migrants (Saptohutomo, 2012; Hermon, 2015). Based on this, researchers are interested in knowing more about the harmony of ethnic relations in Malaysia. Thus, the purpose of this study was to describe people's perceptions of the harmonization of inter-ethnic social relations in Malaysia. 
The type of research used is descriptive qualitative research, to analyze public perceptions of the harmonization of ethnic social relations in Malaysia. The method used in this research is a descriptive method (Hermon et al., 2008) in the form of an overview of the facts found in the field, with the sampling technique that is accidental sampling, where the sample is the Malaysian community which was found when the research was carried out. The type of data used in this research is primary data, which was obtained at the time the research was carried out. Data collection techniques used were through interviews and documentation, interviews were conducted with the Malaysian community to obtain data that was in accordance with the research objectives.

\section{Results and Discussion}

Harmonization is an effort to find harmony, with the effort that allows the community to establish a harmonious relationship will make it easier for the community to establish good cooperation in a society that has various cultural differences, in that difference many things can happen, so the need to maintain or strengthen one another individual relationships with each other. A harmonious relationship will have a good impact on the community, which can later be used as a capital of togetherness for future generations. A relationship occurs when two people influence each other, if one depends on the other (Sears, 1988). Whereas social in this case concerning social relations are all human relations that describe good relations, which happened in Patila village, North Luwu district, as for social theory, namely: functional theory is an approach in the social sciences that has an interest in analyzing the functions of social institutions (Fahrudin, 2012). Human development in carrying out social interaction between individuals and individuals or between groups with social relations groups is divided into two based on their status: Closed relationships, namely social relations that occur in a particular social group. For example, the nobility associated with the nobility. And open relationships, namely forms of social relations caused by differences in status in the community not by social groups. For example, the relationship between leadership and subordinates, the relationship between teachers and students and so on. Closed relationships in social life can occur due to the pattern of thinking of people who still see differences in degrees. Whereas open relationships are caused by differences in status, this is common between leaders and subordinates because subordinates and leaders have different positions (Nike, 2013).

Each society has a different value system that is passed from generation to generation to generation. Values can be derived from religious values, customs values and aesthetic values that continue to evolve in line with the civilization of previous societies. Social value is everything that is considered good and true by some the community. Social value arises from the individual values possessed by a person. Through association, individual values finally get approval from the wider community so that it becomes the social value of society. As an example of social values that exist in society is, behave politely and honestly; be wise and wise; have strong faith and piety; be fair and be friendly. Physically social norms are concrete forms of social values that exist in a society. This social norm is a written or unwritten rule. In order for social norms to be implemented it is necessary to enforce norms accompanied by sanctions. If these sanctions have not fostered compliance, sanctions can be maximized and their application is accompanied by coercion by the State apparatus (police and prosecutors and judiciary officials). In modern society, social norms vary greatly in number and type, often not detected in detail by some community members (Widiadmoko, 2013). Ethnic or ethnic groups are recognized by society and by ethnic groups themselves as a separate group. The term ethnics thus concerns not only racial groups, but also concerns other groups that have the same origins, and have links with one another in terms of religion, language, nationality, regional origin or a combination of one factor with other factors (Narwoko, 2007). Malaysia is a federal country consisting of thirteen countries (states) and three federal regions in Southeast Asia with an area of 329,847 sq. Km. The capital is Kuala Lumpur, while Putrajaya is the center of the federal government. The population of this country exceeds 27 million. The country is divided into two regions - West Malaysia and East Malaysia - by the Natuna Islands, the territory of Indonesia in the South China Sea. Malaysia is bordered by Thailand, Indonesia, Singapore, Brunei and the Philippines. The country is located near the equator and has a tropical climate. The head of state of Malaysia is a King or a Sultan Malaysia with a multi-ethnic, multi-cultural and multi-lingual society. 
There are three major ethnic groups that exist or live and coexist in Malaysia, namely: (1) Malays, Malays, the largest ethnic group in Malaysia, have a population of more than 50\%. In Malaysia, the Malay term refers to someone who adheres to Islam and practices the Malay tradition, speaks Malay and has a Malay ancestor. His change to Islam from Hindu and Theravada Buddhist teachings began in the 1400s, largely influenced by the decision of the kingdom of Malacca. Malays are known for their gentle behavior and rich artistic heritage, (2) China, the second largest ethnic group, Chinese Malaysians fill about 25\% of the population. Most descended from Chinese immigrants during the 19th century, the Chinese were known for their perseverance and sharp business thinking. Three subgroups that speak Mandarin with different dialects are Hokkians who generally live on the northern island of Penang; Cantonese who generally live in the capital Kuala Lumpur; and groups that speak Mandarin that generally live in the southern state of Johor, (3) India, As the smallest of the three main ethnic groups, Malaysian Indians make up about $10 \%$ of the population. Most of the descendants of Tamil-speaking South Indian immigrants who came to the country during the British colonial rule. Driven by the prospect of leaving the caste system in India, they came to Malaysia to build a better life. in general they are Hindus, and they bring with them their colorful culture such as temples full of decorations, spicy cuisine and beautiful sari cloth (Malaysia Travel, 2017).

In addition to these three ethnic groups in Malaysia there are also non-Melayau indigenous tribes. The largest non-Malay native tribe is Iban from Sarawak, whose numbers exceed 600,000. Some Iban tribes still live in traditional forest settlements within longhouses along the Rajang and Lupar Rivers and their watersheds, although many of the Iban Tribe moved to the city. The Bidayuh tribe, totaling approximately 170,000 people, is based in the southwest of Sarawak. The largest indigenous tribe in Sabah is Kadazan. They are generally farmers who embrace Christianity. 140,000 Orang Asli, or aboriginal, consist of a number of different tribal communities who settled in West Malaysia. Usually hunters, shifting cultivators, and farmers, many of them later settled and some mixed into modern Malaysia. In addition, there are also Eurasians, Cambodians, Vietnamese, Thai, Bugis, Javanese, and indigenous tribes to enrich the diversity of the Malaysian population. A small number of Eurasians, a mixture of Portuguese and Malay, Portuguesebased creole language, are called Kristang languages. There are also Filipino and Spanish mixed Eurasians, especially in Sabah. Derived from immigrants from the Philippines, some speak Chavacano, the only Spanish-based creole language in Asia. Cambodians and Vietnamese are mainly Buddhists (Cambodia: Theravada sect, Vietnamese: Mahayana sect). Thai-Malaysians are a large group in the states of Perlis, Kedah, Penang, Perak, Kelantan, and Terengganu. Besides speaking Thai, most of them are Buddhists, celebrate Songkran (water festival) and can speak Hokkien but some of them are Muslim and speak Malay in the Kelantan dialect. The Bugis and Javanese became part of the population in Johor. In addition, there are also many foreigners and expatriates who make Malaysia their second home, also contributing to Malaysia's population. Malaysia has become the home of various ethnic, religious and ethnic communities. With its multiethnic nature, various forms of culture, language, religion and customs are formed. The style of Malaysian society like this is the impact of changes in its political structure. Prior to the 19th century, the majority of Malaysians (formerly known as Tanah Melayu) were predominantly Malays plus indigenous people, and a small number of other ethnic groups. Therefore this region is better known as the Malay Peninsula.Based on the results of interviews conducted with Malaysian citizens who were encountered during the research process related to people's perception of the harmonization of ethnic amar social relations in Malaysia, the results were good. According to the community, the relationships that are established between each other and between ethnic groups are going well, without large conflicts. According to the community, they have lived side by side even though not infrequently helping ethnic groups. Although, it was acknowledged by some informants that with the development of the era, the established social relations were loosened enough because the people now began to pay less attention to the surrounding events, for example when in a public vehicle compared to talking or communicating with other ethnic groups or between ethnic groups of the majority of the community preferring to focus on smartphones, and not infrequently according to the sources' testimonies to avoid contact with the public preferring to use earphones while playing smartphones, this is what according to the informants causing a decrease in inter-ethnic interaction.

Even though harmony can be realized well, it cannot be separated from the essence of social relations between religions. However, once again the interviewee emphasized that even so the relations between ethnic groups continued to go side by side and each ethnic group respected other ethnicities. This is according to the informant who maintains the harmony of inter-ethnic social relations in Malaysia. Although, 
some informants, especially ethnic, besides Malay, still complained about the different treatment they had received from the government, most of them Malay. Even though the government should act fairly and give equal rights to every citizen regardless of the status or ethnicity of its citizens. However, overall the perception of the Malaysian community considers that social relations between ethnic groups still run in harmony.

\section{Conclusion}

Based on the results of the research, a decision can be made that the society perception of ethnic social relations is well established, where the community always maintains harmony even though in the existing ethnic diversity, the differences in each ethnicity are not things that can cause discomfort in social life. However, ethnic groups other than Malay still often receive unfair treatment from the Malaysian government, because of the government's view that ethnic Malays are the best ethnic, while ethnic groups, such as Ina, are migrants trying to take the economic skills of the nation and Indian tribes are low tribes and are usually very difficult to get a good job, especially work in government. However, in practice, especially from the point of view or public perception, it is known that inter-ethnic social relations in Malaysia remain well established without intrigue that can divide the nation, even though they also recognize that there are still differences between ethnic groups but still in a reasonable context, because indeed it is very difficult to unite different things into one.

\section{References}

Aksara, I.E. 2012. Ilmu Sosial Budaya Dasar. Yogyakarta: Ombak.

Damanhuri H dan Putra A. 2015. Profil Investasi (Pengembangan Potensi Unggulan Daerah Pada Pulau Kecil Di Kabupaten Pasaman Barat). Badan Penanaman Modal dan Pelayanan Perizinan Terpadu Kabupaten Pasaman Barat.

Damanhuri H, Nurhuda, Darmayanti Y dan Putra A. (2016). Profil Pariwisata Nagari Kajai (Pengembangan Potensi Daerah Kecamatan Talamau, Kabupaten Pasaman Barat). Badan Penanaman Modal dan Pelayanan Perizinan Terpadu Kabupaten Pasaman Barat

Fahrudin, A. 2012. Pengantar Kesejahteraan Sosial. Bandung: PT Refika Aditama.

Hasan, S. 1983. Sosiologi Untuk Masyarakat Indonesia. Cet. IX; Jakarta: Bina

Hermon, D., Khairani., Daswirman., S. Karim., Dasrizal., and Triyatno. 2008. Metode dan Teknik Penelitian Geografi Tanah: Aplikasi Instrumen dan Acuan Penelitian Geografi Fisik. Yayasan Jihadul Khair Center.

Hermon, D. 2010. Geografi Lingkungan: Perubahan Lingkungan Global. UNP Press.

Hermon, D. 2012. Mitigasi Bencana Hidrometeorlogi: Banjir, Longsor, Degradasi Lahan, Ekologi, Kekeringan, dan Puting Beliung. UNP Press. Padang.

Hermon, D. 2015. Geografi Bencana Alam. Jakarta: PT RajaGrafindo Persada.

Hermon, D. 2016. Mitigasi Perubahan Iklim. Rajawali Pers (Radjagrafindo).

Hermon, D. 2017. Climate Change Mitigation. Rajawali Pers (Radjagrafindo).

Hermon, D., Y. Suasti., Ernawati., Afdhal., and H. Edial. 2018. Geografi: Geografi untuk SMU. Jurusan Geografi Universitas Negeri Padang.

Mulyana, D. 2005. Komunikasi Efektif: Suatu Pendekatan Lintas Budaya. Bandung: Remaja Rosdakarya.

Malaysia T. 2017. Budaya dan Warisan : Masyarakat. http://www.malaysia.travel/id- id/my/aboutmalaysia/culture-n-heritage/people. Diakses tanggal 05 Agustus 2018.

Nike., A. 2013. Bentu-Bentuk Hubungan Sosial. http://aalnike.blogspot.com/2013/03/ makalahbentukbentuk-hubungan-sosial.htmlan-sosial.html. Diakses tanggal 05 Agustus 2018

Narwoko, D. 2007. Sosiologi Teks Pengantar Dan Terapan. Jakarta: Kencana Prenada Poerwanto, Hari. 2000. Kebudayaan Dan Lingkungan Dalam Perspektif Antropologi. Yogyakarta: Celeban Timur. 
Rasyid, M. 2011. Mengenal Sosiologi Suatu Pengantar. Makassar: Alauddin University Press

Saptohutomo, A.P. 2012. Malaysia, Negeri Rasis Berwajah Manis. https://www.merdeka. com/dunia/malaysia-negeri-rasis-berwajah-manis.html. Diakses tanggal 05 Agustus 2018

Sears, D. 1988. Psikologi Sosial. Jakarta: PT. Gelora Aksara Pratama.

Setiadi, M. E. 2006. Ilmu Sosial Dan Budaya Dasar. Jakarta: Kencana Prenada Media Group Veeger. 1985. Refleksi Filsafat Sosial Atas Hubungan Individu-Masyarakat Dalam Cakrawala Sejarah Sosiologi. Jakarta: PT. Gramedia Pustaka Utama.

Walgito, B. 1980. Pengantar Psikologi Umum. Yogyakarta: C.V Andi Offset. Weber, Max. 2006. Sosiologi. Yokyakarta: Celeban Timur.

Widiadmoko, S. 2013. Sosiologi. Sidoarjo: PT. Mas Media Buana Pustaka. 